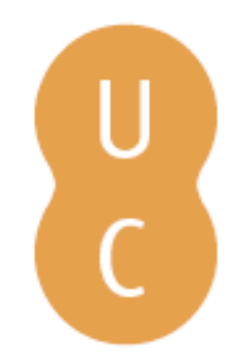

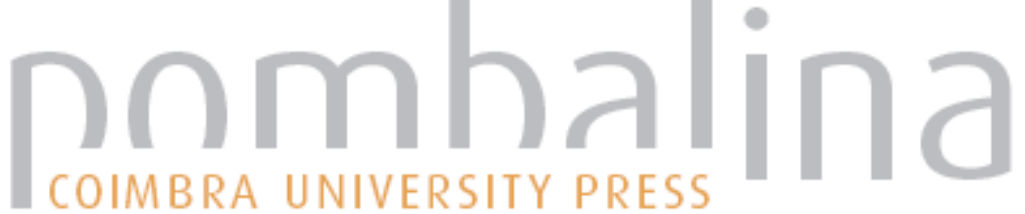

\section{Implementation of different techniques for controlling post-fire erosion in the N.W. of the Iberian Peninsula}

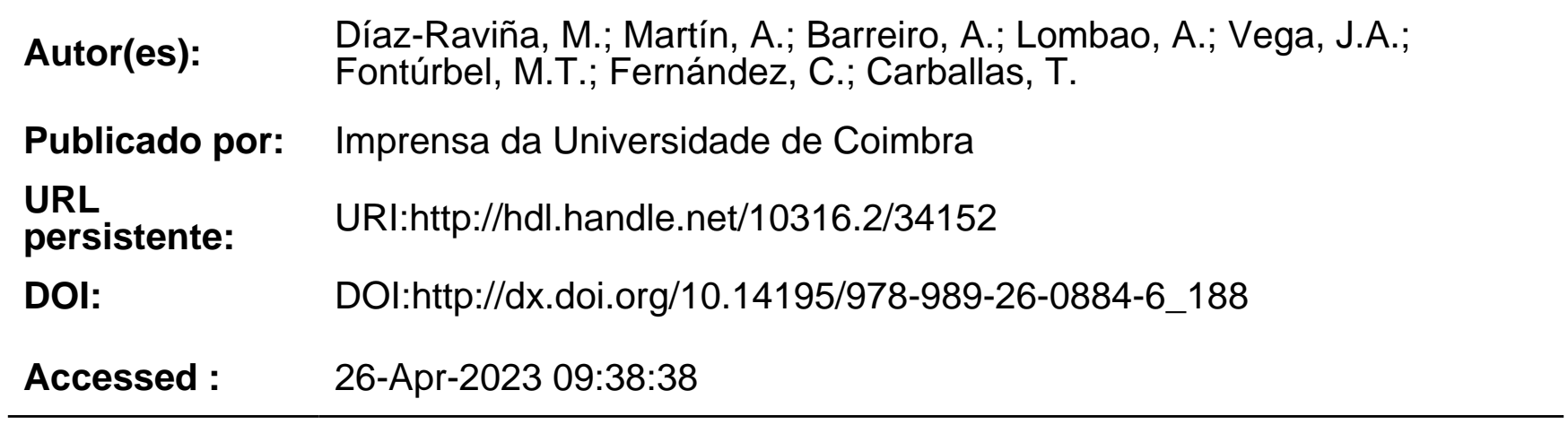

A navegação consulta e descarregamento dos títulos inseridos nas Bibliotecas Digitais UC Digitalis, UC Pombalina e UC Impactum, pressupõem a aceitação plena e sem reservas dos Termos e Condições de Uso destas Bibliotecas Digitais, disponíveis em https://digitalis.uc.pt/pt-pt/termos.

Conforme exposto nos referidos Termos e Condições de Uso, o descarregamento de títulos de acesso restrito requer uma licença válida de autorização devendo o utilizador aceder ao(s) documento(s) a partir de um endereço de IP da instituição detentora da supramencionada licença.

Ao utilizador é apenas permitido o descarregamento para uso pessoal, pelo que o emprego do(s) título(s) descarregado(s) para outro fim, designadamente comercial, carece de autorização do respetivo autor ou editor da obra.

Na medida em que todas as obras da UC Digitalis se encontram protegidas pelo Código do Direito de Autor e Direitos Conexos e demais legislação aplicável, toda a cópia, parcial ou total, deste documento, nos casos em que é legalmente admitida, deverá conter ou fazer-se acompanhar por este aviso.

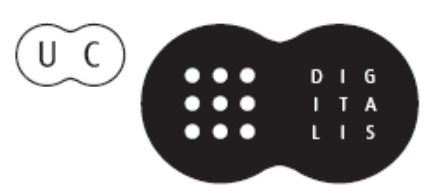




\section{ADVANCES IN}

Forest Fire

\section{RESEARCH}

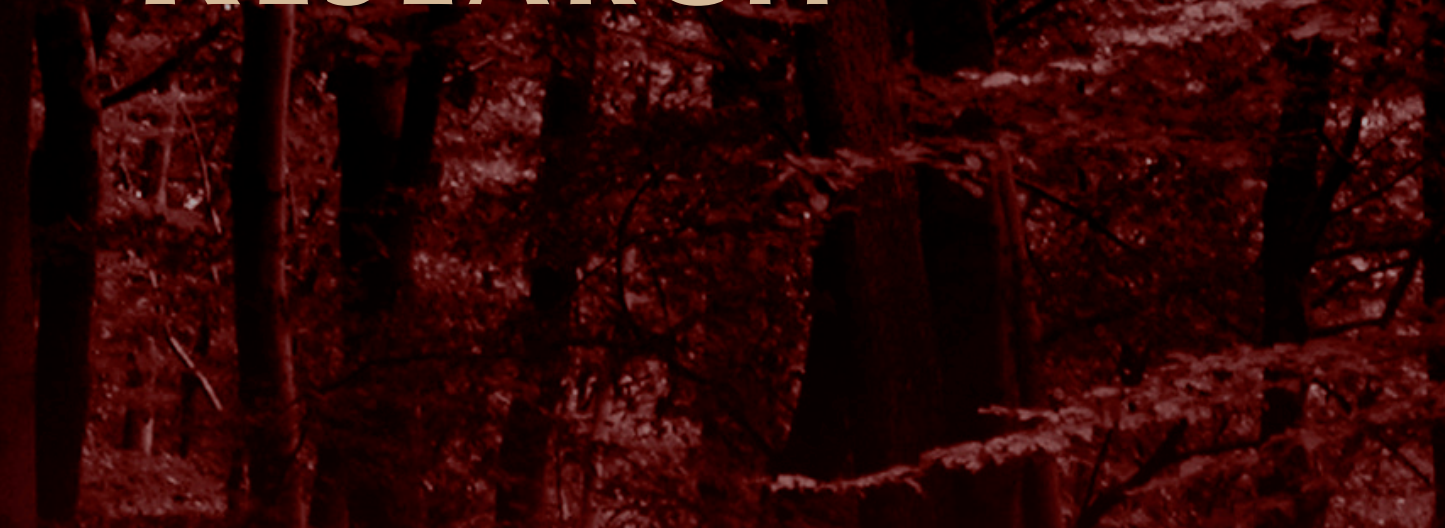

\section{DOMINGOS XAVIER VIEGAS}

\section{EDITOR}




\title{
Implementation of different techniques for controlling post-fire erosion in the N.W. of the Iberian Peninsula
}

\author{
M. Díaz-Raviña ${ }^{\mathrm{a}}$, A. Martín ${ }^{\mathrm{a}}$, A. Barreiro ${ }^{\mathrm{a}}$, A. Lombao ${ }^{\mathrm{a}}$, J.A. Vega ${ }^{\mathrm{b}}$, M.T. Fontúrbel $^{\mathrm{b}}$, C. Fernández $^{\mathrm{b}}$, \\ T. Carballas ${ }^{a *}$ \\ ${ }^{a}$ Departamento de Bioquímica del Suelo, Instituto de Investigaciones Agrobiológicas de Galicia \\ (IIAG-CSIC), P.O. Box 122, 15780 Santiago de Compostela, Spain, *tcf@iiag.csic.es \\ ${ }^{b}$ Centro de Investigación Forestal-Lourizán, Consellería de Medio Rural e do Mar, P.O Box 127, \\ 36080 Pontevedra, Spain, maria.teresa.fonturbel.lliteras@xunta.es
}

\begin{abstract}
The effect of two post-fire stabilization treatments (seeding and mulching) on some selected physical, chemical, biochemical and microbiological properties as well as the efficacy of these treatments on post-fire erosion control was investigated. The study was performed in two scrubland areas of Galicia (N.W. Spain), susceptible to suffer post-fire erosion (slope 30-50\%) after an experimental fire and a wildfire, respectively. Soil samples were taken from the A horizon at different sampling times over one year after the fire event as well as from the corresponding unburnt soil located in an adjacent plot used as control; the sediments from the burnt soils, with and without different post-fire stabilisation treatments, were periodically collected after precipitation events. The results showed that initially the wildfire induced important changes in most properties measured and that these effects persisted 12 months after the fire; in contrast, the experimental fire provoked slight changes in the physic-chemical and chemical properties but moderate changes in the biochemical properties. They also indicated that both stabilisation treatments had no effects on the soil properties analysed and then on soil quality, but reduced significantly the sediments yield compared to the control burnt soil. The mean efficiency of the seeding and mulching treatments in preventing soil erosion was $21-31 \%$ and $85-88 \%$, respectively, showing that, in the short- and medium-term (12 months), the straw mulching was the most effective treatment for reducing the post-fire erosion in both burnt areas.
\end{abstract}

Keywords: experimental fire, wildfire, soil quality, post-fire soil erosion, post-fire rehabilitation.

\section{Introduction}

High severity forest wildfires are common in the N.W. of Spain and the risk of post-fire erosion is very high due to the presence of forest ecosystems located in pronounced relief terrains, in combination with abundant precipitations (Carballas 2014; Carballas et al. 2009; Vega et al. 2013). It is well known that post-fire stabilisation treatments such as seeding, mulching and erosion barriers can reduce surface runoff and keep post-wildfire soil in place and thereby prevent sediment deposition in unwanted areas, being regarded as a defensive first line against post-fire erosion and sediments movement (Robichaud et al. 2005). Therefore, the implementation of post-fire stabilisation techniques in burnt forest ecosystems could reduce post-fire erosion; however, studies on this topic are scarce and have been mainly performed in USA. Since post-fire stabilisation treatments are expensive they should only be applied where and when they are required; therefore, studies on monitoring the efficacy of these techniques are necessary to compare their effectiveness and determine if they should be implemented in burned areas of the N.W. of the Iberian Peninsula. The aim of this investigation was to evaluate the effectiveness of two stabilisation techniques, seeding and mulching, in reducing soil erosion as well as their effects on the soil quality. 


\section{Methods}

The study was performed on two scrubland hill slopes areas located in Galicia (N.W. of Spain), one affected by an experimental fire of low severity (Monte Cabalar, Pontevedra; E soil), and the other affected by a high severity wildfire (Laza, Ourense; W soil) and highly susceptible to suffer post-fire erosion (slope 30-50\%). In both areas, experimental plots (E soil, $30 \mathrm{~m}$ long x $10 \mathrm{~m}$ wide; W soil, 20 $\mathrm{m}$ long x $5 \mathrm{~m}$ wide) were installed by triplicate (W soil) or quadruplicate (E soil) and four treatments were established: unburnt control soil (U); burnt control soil (B); burnt soil with seeding $(\mathrm{B}+\mathrm{S}$; a mixture of seeds at a rate of $45 \mathrm{~g} \mathrm{~m}^{-2}$ in the E soil; and rye seeds at a rate of $10 \mathrm{~g} \mathrm{~m}^{-2}$ in the $\mathrm{W}$ soil); and burnt soil with straw mulch (B+M; straw at a rate of $250 \mathrm{~g} \mathrm{~m}^{-2}$ ) (Figs. 1. 2, 3). For the different soil treatments, the sediments production (Figure 4) as well as the analysis of different physical, chemical and microbiological properties of the soil samples collected from the A horizon $(0-5 \mathrm{~cm})$ was performed over an one year period. A detailed description of the experimental set up as well as the methods used for the sediments and soil characterization are given in Fontúrbel et al. (2012) and DíazRaviña et al. (2012). Soil characterization included a wide range of physical (texture, water retention, water repellence, aggregate stability), physic-chemical $(\mathrm{pH}$, electric conductivity), chemical (total $\mathrm{C}$, soluble $\mathrm{C}$, soil carbohydrates, total $\mathrm{N},{ }^{13} \mathrm{C},{ }^{15} \mathrm{~N}$, inorganic $\mathrm{N}$, macro- and micro-nutrients) and biochemical and microbiological (microbial biomass, soil enzymes of $\mathrm{C}, \mathrm{N}$ and $\mathrm{P}$, bacterial activity, soil respiration, microbial biomarkers such as phospholipids fatty acids -PLFA pattern) properties, as well as sediment characterization, performed at different sampling times over one year period. However, to facilitate the interpretation of data, only 11 soil properties measured 1 day and 365 days after the application of the treatments were here used for evaluating the soil quality status in the two experimental burned areas.

In order to evaluate the effect of the fire and the post-fire stabilisation treatments, the values of threefour plots with the same treatment were averaged (mean \pm SE). The data were analyzed by a standard analysis of variance (ANOVA1) and, in the cases of significant F statistics, the Turkey's minimum significant difference test was used to separate the means. In addition, a principal component analysis (PCA) was carried out on the physical, chemical and biochemical data for the evaluation of the soil status. All statistical analyses were made using SPSS 15.0 statistical package.

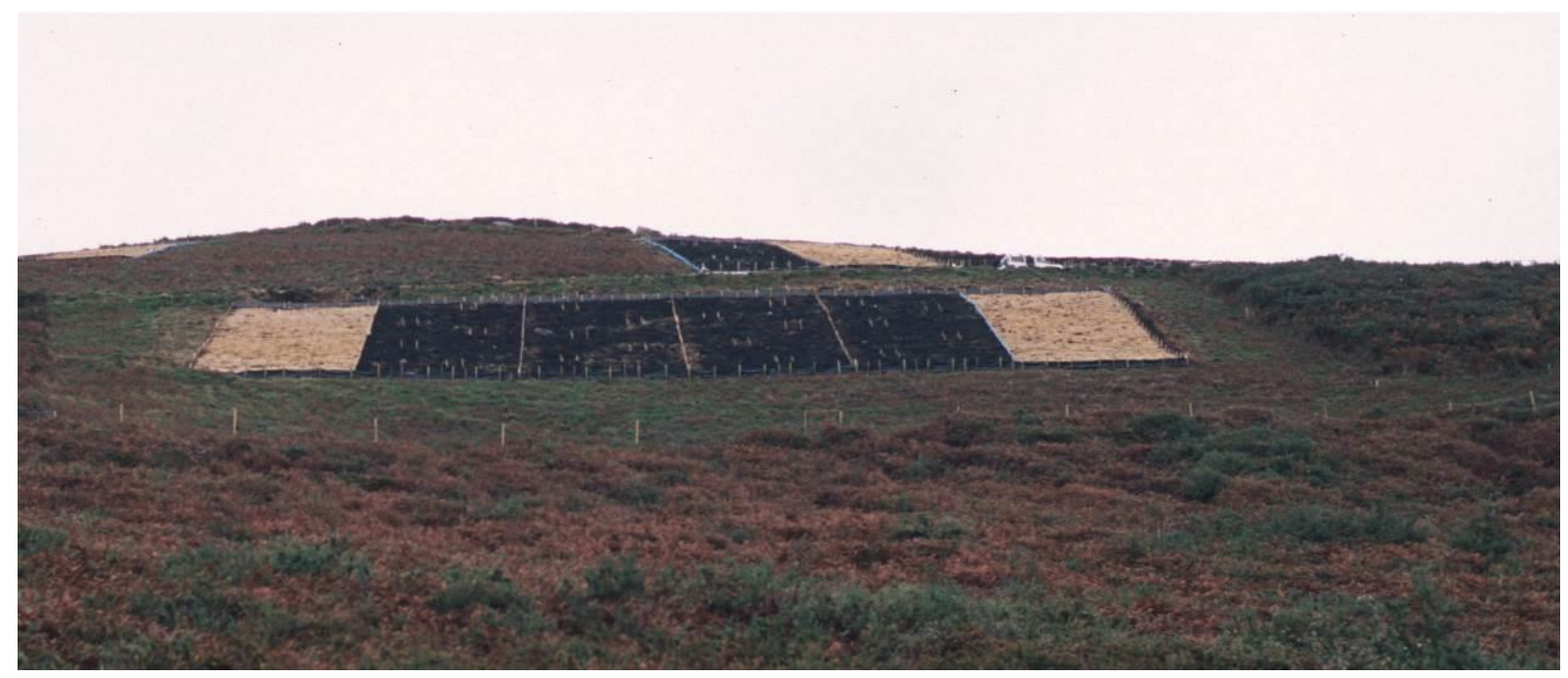

Figure 1. Partial view of the macro-plots in the area affected by an experimental fire (Monte Cabalar, A Estrada, Pontevedra; $E$ soil). 


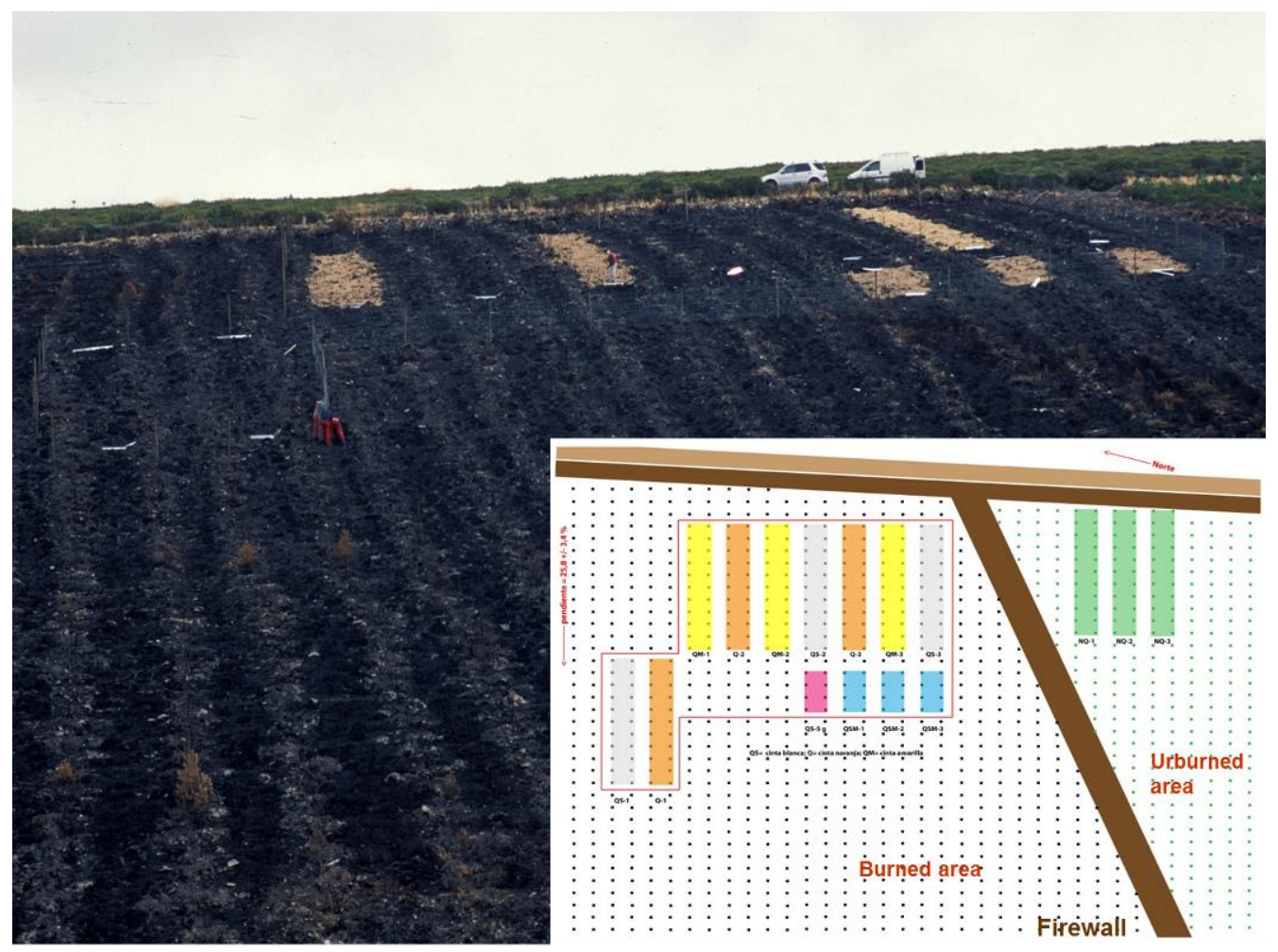

Figure 2. Partial view of the experimental area affected by a wildfire (Laza, Ourense; $W$ soil).

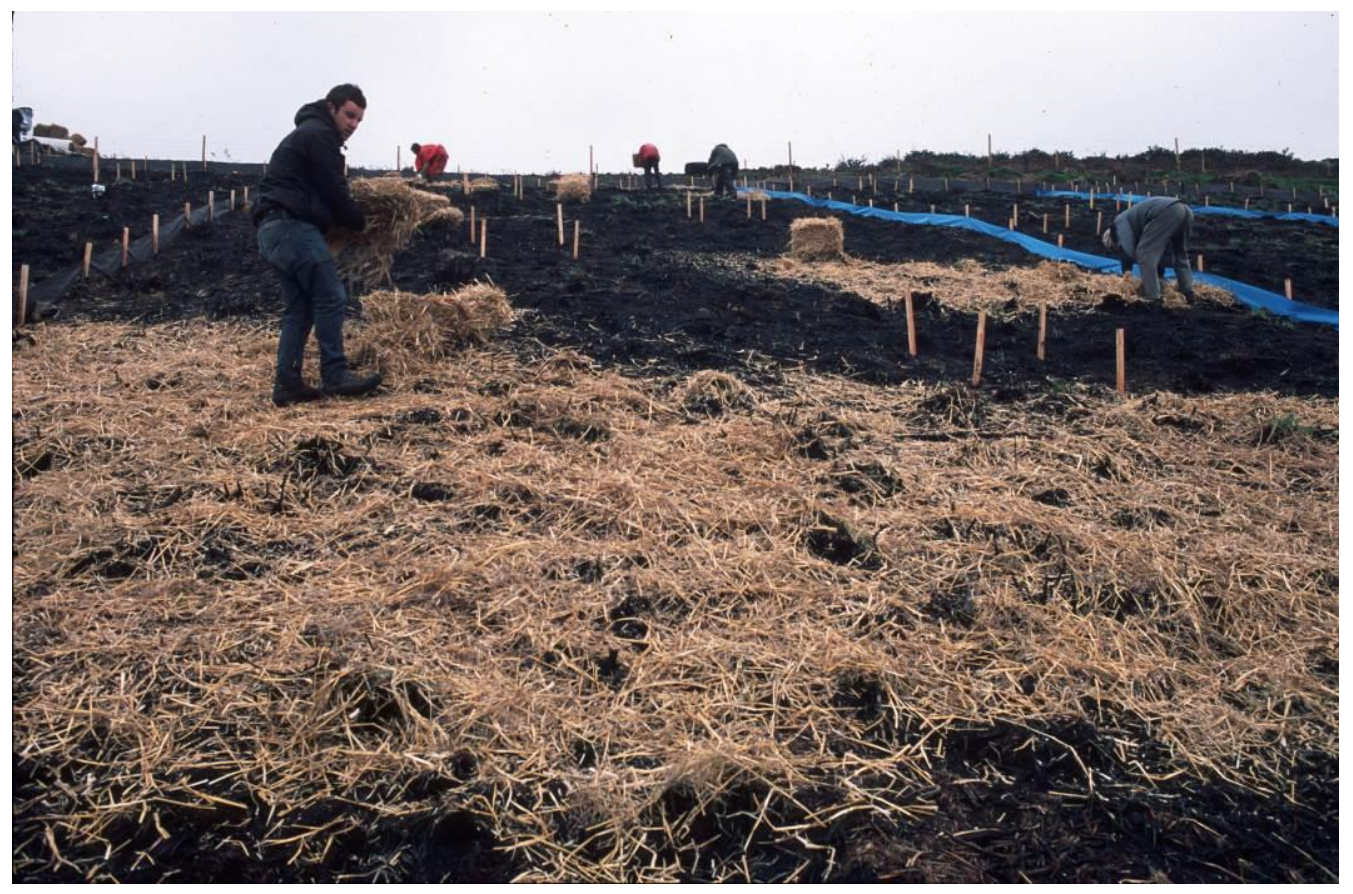

Figure 3. Burnt soil protection against post-fire erosion with straw mulching. 


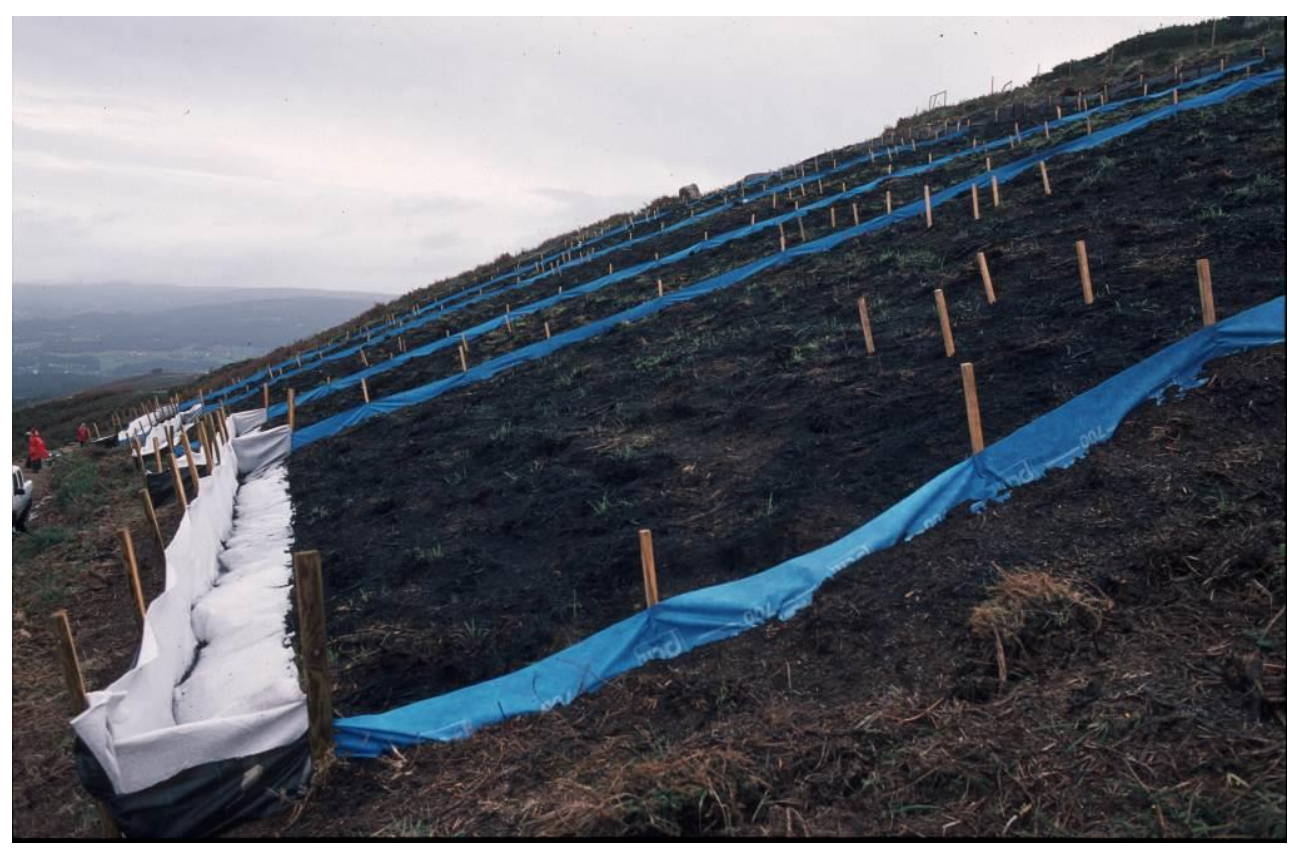

Figure 4. View of the macro-plots delimited by geotextile fabrics to measure post-fire erosion.

\section{Results and discussion}

The main topsoil characteristics of the unburnt and burnt soil samples 1 day and 365 days after the wildfire are showed in Figures 5 and 6 . The soils studied had an acid $\mathrm{pH}$, elevated content of organic matter and microbial biomass $\mathrm{C}$ and low nutrient availability and microbial activity values, these results being representative of forest soils under shrub land vegetation in the Atlantic humid temperate zone of the N.W. of the Iberian Peninsula. Compared to the corresponding unburnt soil samples (U), significant positive or negative effects in most physic-chemical, chemical and biochemical properties were observed immediately after the wildfire (W soil) and less marked or even no significant changes in the soil affected by the experimental fire (E soil). These results can be explained by the temperatures reached during the fire event; the prescribed fire was of low severity, reaching temperatures of $153^{\circ} \mathrm{C}$ in the mineral soil surface and $34^{\circ} \mathrm{C}$ at $2 \mathrm{~cm}$ soil depth (Fontúrbel et al. 2012) whereas the uncontrolled fire was of moderate to high severity as it was indicated by the presence of black and white ashes and the total consumption of the ground plant communities (Vega et al. 2013). The microbial biomass and the activity values were lower in the burnt soils than in the corresponding unburnt soils, indicating that the fire had negative effects on the microbial population (death of microorganisms by soil sterilization). It should be noticed that for both soils, the fire induced more marked changes in the biochemical properties (microbial $\mathrm{C}$, glucosidase activity, urease activity) than those observed in the physic-chemical and chemical properties. This is consistent with earlier studies performed with soils from the same region showing the usefulness of the more labile and active fraction of the soil organic matter, the microbial component, to detect the impact of prescribed fires (Barreiro et al. 2010; Basanta et al. 2004) or wildfires of medium and high intensity (Prieto et al. 1998; Villar et al. 2004).

One year after the wildfire, except for the electric conductivity, the burnt soils showed values for the physic-chemical, chemical and biochemical parameters different from those reported for the corresponding unburnt soil, indicating that the adverse fire impact persisted over time. This behaviour can be explained by the high temperatures reached during the fire as well as the low recovery of the vegetation. 


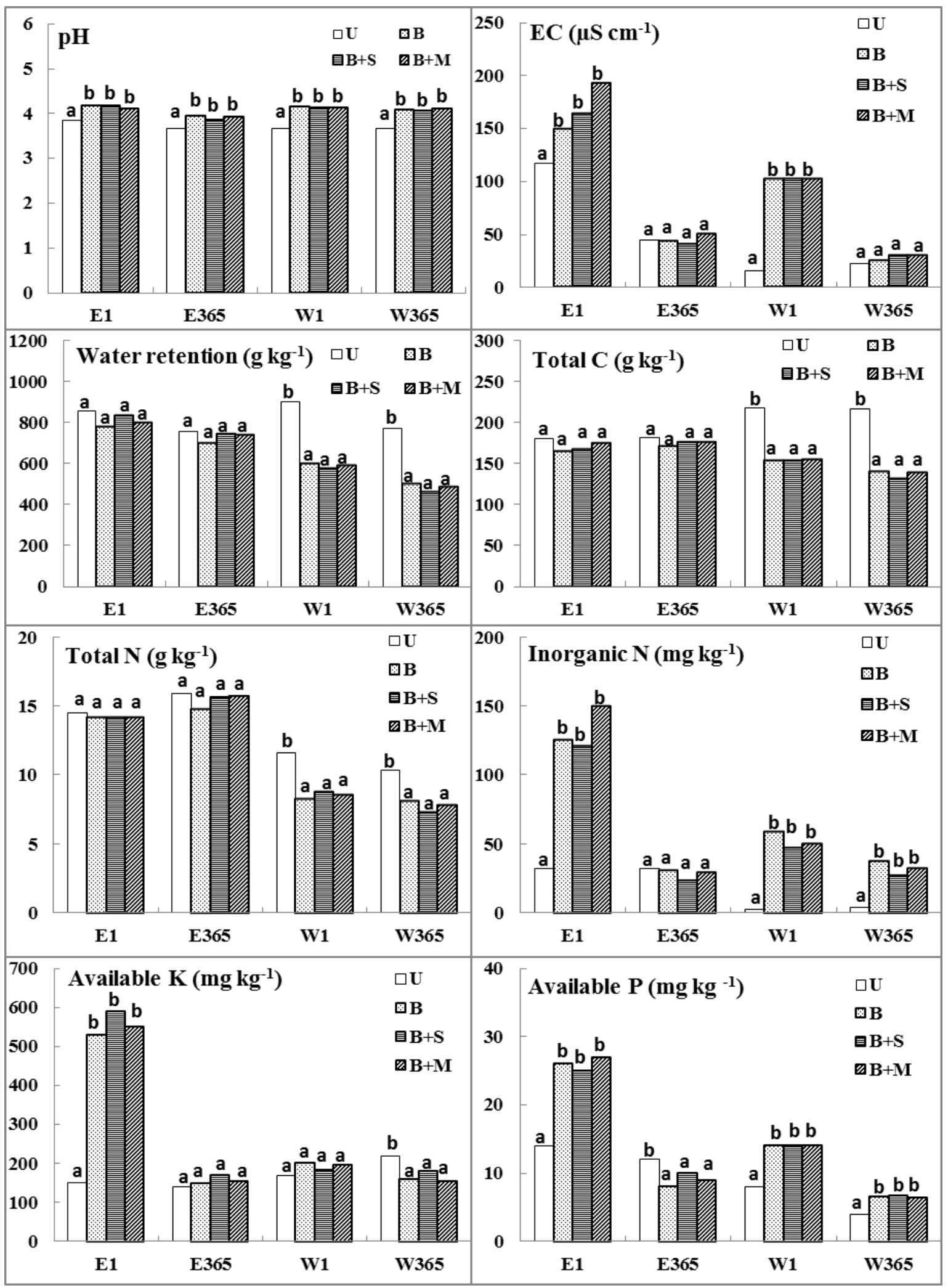

Figure 5. Soil physical and chemical properties for the different soil treatments 1 day and 365 days after the experimental fire $(E)$ or the wildfire $(W)$ (mean values of 3-4 replicates). Treatments: $U$, unburnt soil; $B$, burnt soil; $B+S$, burnt soil plus seeding; $B+M$, burnt soil plus straw addition. For the same soil and sampling time different letters denote significant differences $(p<0.05)$ among treatments. Available nutrients were taken from Gómez-Rey et al. (2013) and Gómez-Rey and González-Prieto (2014). 


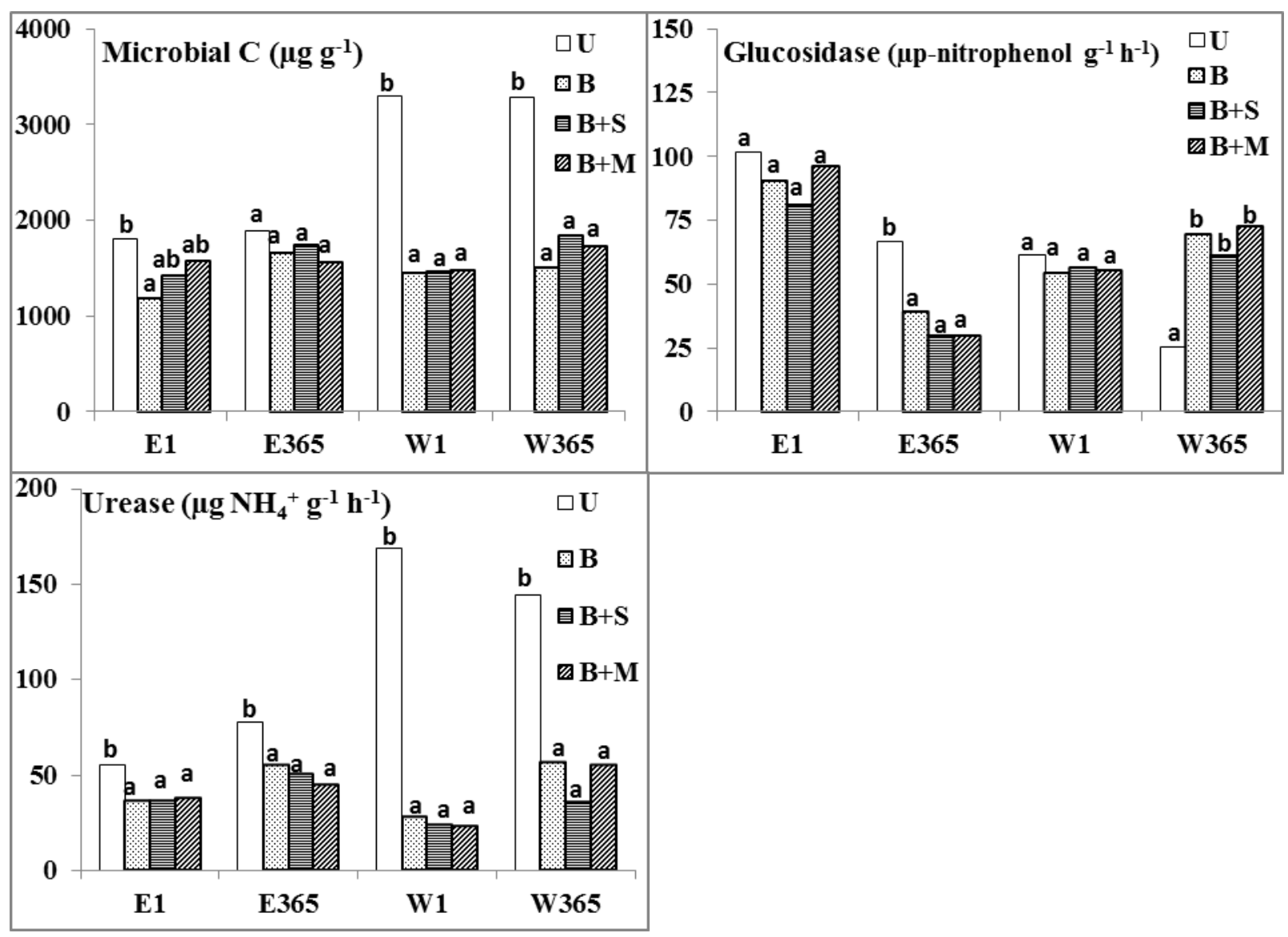

Figure 6. Soil biochemical properties in the different soil treatments 1 day and 365 days after the experimental fire $(E)$ or the wildfire $(W)$ (mean values of 3-4 replicates). Treatments: $U$, unburnt soil; B, burnt soil; B+S, burnt soil plus seeding; $B+M$, burnt soil plus straw addition. For the same soil and sampling time different letters denote significant differences $(p<0.05)$ among treatments.

With regard to the experimental fire, a positive fire influence on $\mathrm{pH}$ and a negative effect on the glucosidase and the urease activities were still maintained after 365 days.

The comparison of the values obtained for the selected soil properties analyzed in the burnt plots under seeding and mulching treatments $(\mathrm{B}+\mathrm{S}, \mathrm{B}+\mathrm{M}) 365$ days after the fire with those of the corresponding untreated burnt soil (B) allowed us to determine the effect of these two post-fire stabilisation treatments on the soil quality. Likewise, the analysis of the sediments corresponding to the above treatments allowed us to determine their effectiveness on the control of soil erosion. The results clearly indicated that, independently of the fire event, there were no significant differences between the $\mathrm{B}+\mathrm{S}$ and $\mathrm{B}+\mathrm{M}$ treatments and the corresponding burnt control (B) for any of the soil properties studied, which showed that at least after one year these two stabilisation treatments did not modify the burnt soil quality (Figures 5 and 6).

In order to compare the soil quality in the unburnt and the burned samples collected in the two experimental areas, all physic-chemical, chemical and biochemical properties should be used together. Consequently, a Principal Component Analysis (PCA) was used to analyse the 11 soil properties of the whole data set of the samples analyzed $(\mathrm{n}=16$ samples) (Figure 7). The main two factors identified accounted for $68 \%$ of the variance. The factor 1 , which accounted for $42 \%$ of the variance, is defined at its positive extreme by the $\mathrm{pH}$, the electric conductivity, the inorganic $\mathrm{N}$ and the available $\mathrm{P}$; and at its negative extreme by the microbial biomass $\mathrm{C}$ and the urease activity. The 


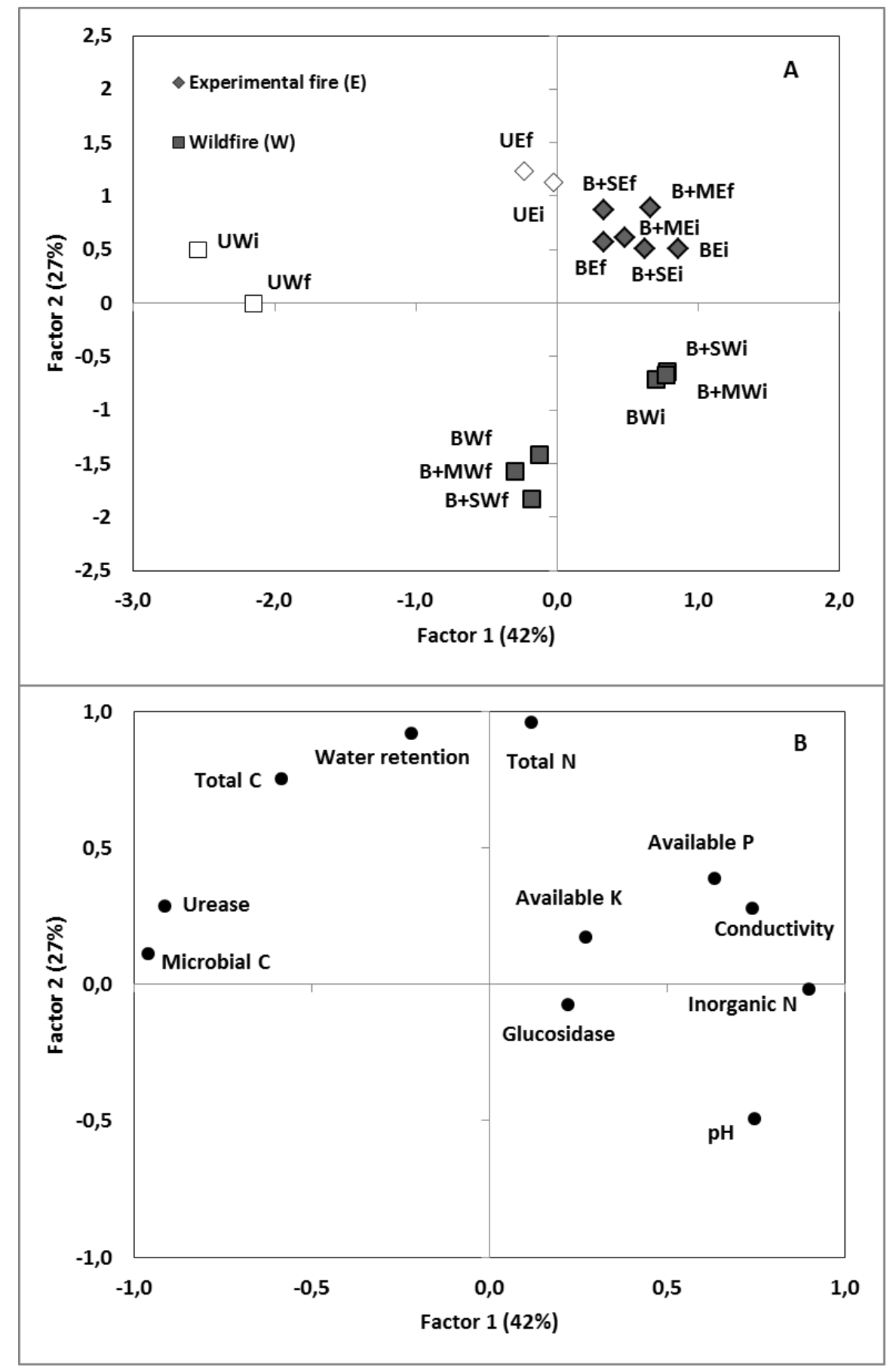

Figure 7. Score (A) and loading plots (B) from principal component analysis performed on the physical, chemical and biochemical properties of the studied soil treatments 1 day $(i)$ and 365 days $(f)$ after the experimental fire $(E)$ or the wildfire (W). Treatments: $U$, unburnt soil; B, burnt soil; B+S, burnt soil plus seeding; B+M, burnt soil plus straw addition.

factor 2, which accounted for $21 \%$ of the variance, is defined at its positive arm by variables related to the organic matter (total $\mathrm{N}$, total $\mathrm{C}$ and water retention). The distribution of the samples in the plane defined by the Factors 1 and 2, make it possible to separate clearly the unburned samples of the soil affected by the wildfire from the corresponding burnt samples and even the burnt soil sample from the two treatments collected at different soil sampling time (1 day and 365 days); and, in a lesser extent, the burnt samples of the soil affected by the experimental fire from the corresponding unburnt control soil, suggesting that the factors 1 and 2 are related to the fire impact. The results showed that the fire 
provoked a decrease in the microbial $\mathrm{C}$, the urease activity and the organic matter content; and an increase in the available nutrients, electric conductivity and soil $\mathrm{pH}$. These findings are consistent with the results obtained in previous studies performed in the same region (Carballas et al. 2009; Martín et al. 2012). Likewise the data indicated that the effect of the wildfire on the soil quality was much more accentuated than that observed for the experimental fire (the unburned samples of the E soil were grouped closer to the corresponding samples from the burnt treatments, whereas the unburned samples of the $\mathrm{W}$ soil were clearly separate from the samples corresponding to the burnt treatments).

With regard to the soil stabilisation treatments effects, it should be noticed that, independently of the experimental area considered, the burned treatments of the same soil $(\mathrm{B}, \mathrm{B}+\mathrm{S}, \mathrm{B}+\mathrm{M})$ are grouped together, indicating that the post-fire stabilisation treatments did not change at medium-term (1 year) the quality of the burnt control soil.

The total loss of soil in the soil affected by the experimental fire and the wildfire within 12 months, without and with two different post-fire stabilisation treatments, is showed in Figure 8 . The values were $3,628 \mathrm{~kg} \mathrm{ha}^{-1}$ in the burnt E soil and 1,206 $\mathrm{kg} \mathrm{ha}^{-1}$ in the burnt W soil, with $60-80 \%$ of sediments production in the 2-5 months following the treatments application. The soil loss values obtained lied in the reported range given for burnt soils of the temperate humid zone (Vega et al. 2013); however, it should be noticed that the area affected by the wildfire (W soil) exhibited lower values than those observed in the area subjected to the experimental fire (E soil). This behaviour can be explained according to the rainfall amount and intensity that differed notably between the two experimental areas, the rain events and the erosive power being higher in the $\mathrm{E}$ soil than in the $\mathrm{W}$ soil. The results clearly indicated that important post-fire erosion processes can occur following a low severity fire and that the climate rather than the fire intensity can be more determinant for the production of sediments under specific environmental conditions such as those in the present study (N.W. of the Iberian Peninsula).

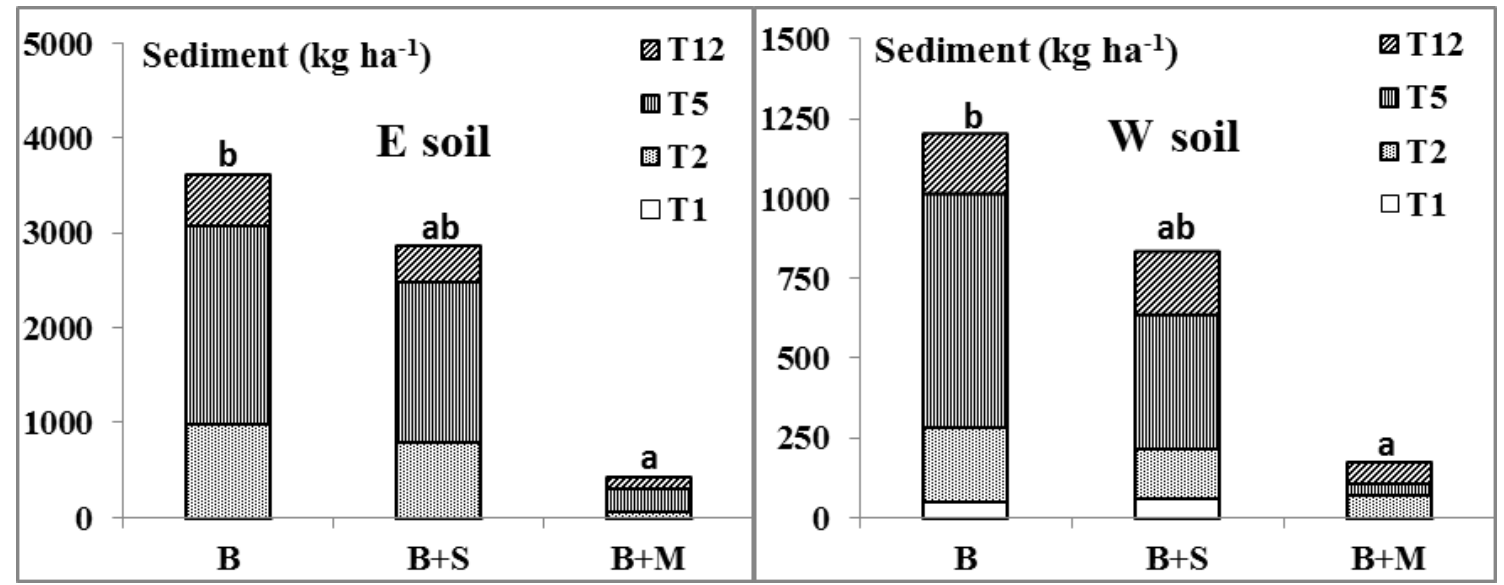

Figure 8. Accumulated sediment yield during the first 1, 2, 5 and 12 months following the experimental fire (E) or the wildfire $(W)$ (11 variables, $n=16$ samples). Treatments: $U$, unburnt soil; $B$, burnt soil; B+S, burnt soil plus seeding; $B+M$, burnt soil plus straw addition.

The soil losses accumulated during the study period from the plots with post-fire stabilisation treatments were much lower than those registered for the burnt control. The sediment yield data indicated that the mulching treatment was the most effective to control the post-fire erosion since compared to the control the soil losses were reduced by $75-95 \%$ in the four evaluation dates, whereas the seeding reduced the soil losses by $20-42 \%$. At the end of the experiment the efficiency of the seeding was $21 \%$ in the $\mathrm{E}$ soil and $31 \%$ in the $\mathrm{W}$ soil, whereas the mulching reduced the erosion by $88 \%$ in the E soil and $85 \%$ in the $\mathrm{W}$ soil; therefore the mean efficiency of the treatments were similar independently of the fire severity. The efficiency values of these soil stabilisation treatments differed 
notably from the values obtained in the NE of Spain (Badía and Martí 2000) but are in accordance with those observed in recent studies performed in the NW of the Iberian Peninsula (Prats et al. 2013; Vega et al. 2013).

\section{Conclusions}

The results showed that initially the wildfire induced important changes in most properties analyzed and that these effects persisted 12 months after the fire; in contrast, the experimental fire provoked slight changes in the physic-chemical and chemical properties but moderate changes in the biochemical and microbiological properties. They also indicated that both stabilisation treatments had no effects on the soil properties analyzed and then on the soil quality, but reduced significantly the sediments yield compared to the control burnt soil. The mean efficiency of the seeding and mulching treatments in preventing soil erosion was $30-40 \%$ and $70-90 \%$, respectively, showing that, in the shortand medium-term (12 months), the straw mulching was the most effective treatment for reducing postfire erosion in both burnt areas. Therefore, taking into account their effects on soil quality as well as their effectiveness, treatments such as seeding and mulching are recommended to control the post-fire erosion in this temperate humid region. However, since post-fire stabilisation techniques are expensive, the straw mulching rather than seeding should be implemented due to its lower cost/benefits ratio.

\section{Acknowledgements}

This study was supported by the Consellería de Medio Rural de la Xunta de Galicia (08MRU002400PR) and by the Ministerio de Ciencia e Innovación (AGL2008-02823) of Spain.

\section{References}

Badía D, Martí C (2000). Seeding and mulching treatments as conservation measures of two burned soils in the central Ebro valley, NE Spain. Arid Soil Research Rehabilitation 13, 219-232.

Barreiro A, Martín T, Carballas T, Díaz-Raviña M (2010). Response of soil microbial communities to fire and fire-fighting chemicals. Science of the Total Environment 408, 6172-6176.

Basanta MR, Díaz-Raviña M, Cuiñas P, Carballas T (2004). Field data of microbial response to a fire retardant. Agrochimica 48, 51-60.

Carballas T (2014). 'El suelo y los incendios forestales en Galicia' (Ed Academia de Farmacia de Galicia), 82 pp. ISBN: 978-84-941537-8-5. (NINO, Santiago de Compostela, Spain)

Carballas T, Martín A, Díaz-Raviña M (2009). Efecto de los incendios forestales sobre los suelos de Galicia. In 'Efectos de los incendios forestales sobre los suelos en España. El estado de la cuestión visto por los científicos españoles'. (Eds A Cerdà, J Mataix-Solera), pp. 269-301. (Cátedra Divulgación de la Ciencia. Universitat de Valencia, Valencia, Spain).

Díaz-Raviña M, Martín A, Barreiro A, Lombao A, Iglesias L, Díaz-Fierros F, Carballas T (2012). Mulching and seeding treatments for post-fire soil stabilisation in NW Spain: short-term effects and effectiveness. Geoderma 191, 31-39.

Fontúrbel MT, Barreiro A, Vega JA, Lombao A, Martín A, Jiménez E, Carballas T, Fernández C (2012). Effects of an experimental fire and post-fire stabilization treatments on soil microbial communities. Geoderma 191, 51-60.

Gómez-Rey MX, Couto-Vázquez A, García-Marco S, González-Prieto SJ (2013). Impact of fire and post-fire management techniques on soil chemical properties. Geoderma 195-196,155-164.

Gómez-Rey MX, González-Prieto SJ (2014). Short and medium-term effects of a wildfire and two emergency stabilization treatments on the availability of macronutrients and trace elements in topsoil. Science of the Total Environment 493, 251-261. 
Martín A, Díaz-Raviña M, Carballas T (2012). Short- and medium-term evolution of soil properties in Atlantic forest ecosystems affected by wildfires. Land Degradation and Development 12, 427-439.

Prats SA, Malvar MC, Vieira DCS, MacDonald L, Keizer JJ (2013). Effectiveness of hydromulching to reduce runoff and erosion in a recently burnt Pine plantation in Central Portugal. Land Degradation and Development. In press, http://dx.doi.org/10.1002/ldr.2236.

Prieto-Fernández A, Acea MJ, Carballas T (1998). Soil microbial and extractable C and N after wildfire. Biology and Fertility of Soils 27, 132-142.

Robichaud PR, Beyers JL, Neary DG (2005). Watershed rehabilitation. In 'Wildland fire in ecosystems: effects on soils and water'. (Eds DG Neary, KC Ryan, LF Debano), pp 179-197. (General Technical Report RMRS-GTR-42-Vol.4. U.S. Department of Agriculture, Forest Service, Rocky Mountain Research Station).

Vega JA, Fontúrbel T, Fernández C, Arellano A, Díaz-Raviña M, Carballas MT, Martín A, GonzálezPrieto S, Merino A, Benito E (2013) (Eds). 'Acciones urgentes contra la erosión en áreas forestales quemadas. Guía para su planificación en Galicia'. (Tórculo Artes Gráficas, Santiago de Compostela, Spain).

Villar MC, Petrikova V, Díaz-Raviña M, Carballas T (2004). Changes in soil microbial biomass and aggregate stability following burning and soil rehabilitation. Geoderma 122, 73-82. 